\title{
O FILME O CONTADOR DE HISTÓRIAS E AS LIÇÕES DA PEDAGOGIA DO AMOR
}

\author{
Denise Azevedo Duarte Guimarães*
}

As imagens não valem pelas raízes libidinosas que escondem, mas pelas flores poéticas e míticas que revelam. (Gilbert Durand)

\begin{abstract}
RESUMO: O artigo focaliza o filme O Contador de Histórias (Luiz Villaça, 2009), baseado na autobiografia de Roberto Carlos Ramos: A arte de construir cidadãos - as 15 lições da pedagogia do amor (2004). Para investigar o gênero textual, à luz da relação entre imaginário, tempo e memória, a análise usa os Estudos Culturais, teorias da narrativa e conceitos educacionais. Enfatiza-se como o filme utiliza um tom irônico, porém emocional e poético, para criticar as falhas educacionais da antiga Fundação Estadual para o Bem Estar do Menor (Febem); em contraste com a ação de uma pedagoga francesa que se dedicou à recuperação do garoto, como um emblemático exemplo de inclusão social. Para concluir, a narrativa é investigada em seu propósito pedagógico, enfatizando educação e cultura como efetivos pilares da cidadania.
\end{abstract}

Palavras-chave: Cinema brasileiro. Autobiografia. Educação. Cidadania.

\section{The MOVIE The STORYTELLER AND THE LESSONS FROM THE PEDAGOGY OF LOVE}

\begin{abstract}
The article focuses the movie The storyteller (Luiz Villaça, 2009), based on Roberto Carlos Ramos's autobiography: The art of forming citizens - the 15 lessons from the pedagogy of love (2004). To investigate the textual genre, in the light of the relation between imaginary, time and memory, this analysis uses Cultural Studies, narrative theories and educational concepts. It highlights how an ironic, and yet emotional and poetic tone is used in the movie in order to criticize the educational failures of the former Febem, in contrast with the actions of a French pedagogue who dedicated herself to the boy's recovery, as an emblematic example of social inclusion. To conclude, it discusses the narrative in its pedagogical purpose, emphasizing education and culture as effective pillars of citizenship.
\end{abstract}

Key words: Brazilian cinema. Autobiography. Education. Citizenship.

\footnotetext{
* Doutora em Estudos Literários e professora adjunta do Mestrado e Doutorado em Comunicação e Linguagens da Universidade Tuiuti do Paraná (UTP).E-mail: denise.guimaraes@utp.br
} 


\title{
LE FILM O CONTADOR DE HISTORIAS ET LES LEÇONS DE LA PÉDAGOGIE DE L'AMOUR
}

\begin{abstract}
RÉSUMÉ: L'article se concentre sur le film O contador de histórias (Luiz Villaça, 2009), basé sur l'autobiographie de Roberto Carlos Ramos: L'art de construire citoyens - les 15 leçons de la pédagogie de l'amour (2004). Pour examiner le genre textuel, à la lumière de la relation entre l'imaginaire, le temps et le souvenir, l'analyse utilise les Études Culturelles, théories du récit et concepts pédagogiques. Il souligne comme le film utilise un ton ironique, toutefois émotionnel et poétique, pour critiquer les imperfections scolaires de l'ancienne Fondation de l'Etat pour le Bien-Etre du Mineur (Febem). De l'autre côté, il relève l'action d'une pédagogue française qui s'est dédiée à la récupération du garçon, comme un emblématique exemple d'inclusion sociale. Pour conclure, le récit est enquêté dans son but pédagogique, en soulignant l'éducation et la culture comme de vrais piliers de la citoyenneté.
\end{abstract}

Mots-clés: Cinéma brésilien. Autobiographie. Éducation. Citoyenneté.

\section{Introdução}

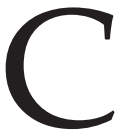

ontextos adversos e aparentemente fadados a anular quaisquer resquícios de cidadania têm sido, reiteradamente, tema e cenário para diversos filmes brasileiros nos quais impera a estética da violência. Raros, porém, são os casos em que experiências subjetivas permitem um novo olhar sobre histórias com "final feliz", quando os inexoráveis efeitos da miséria e das equivocadas políticas públicas são revertidos por alguma espécie de ação inédita e transfiguradora, como ocorre na narrativa fílmica selecionada para análise neste artigo. Tomamos como objeto de estudo o filme O contador de histórias (Luiz Villaça, 2009), que tem como base o livro autobiográfico $A$ arte de construir cidadãos: as 15 lições da pedagogia do amor (2004), escrito por Roberto Carlos Ramos. ${ }^{1}$ Justifica-se a escolha porque a narrativa fílmica parece trafegar na contracorrente de filmes brasileiros, nos quais a infância marginalizada e excluída cai, inevitavelmente, nas malhas do tráfico de drogas e da violência, num caminho sem volta. Destarte, o tema dos meninos de rua não é novo, mas permanece como uma questão ainda mal resolvida, como uma vívida chaga social no coração das metrópoles brasileiras.

Este artigo pretende focalizar a visibilidade cinematográfica da autobiografia que serviu de texto-fonte ao filme, com aporte em teorias da narrativa, de estudos de cinema e das teorias da adaptação, bem como em teorias educacionais; com ênfase não só no processo tradutório do livro, mas igualmente em seu propósito pedagógico e na construção da cidadania.

Tendo consciência da dificuldade de tradução dos conceitos linguísticos ou literários para o cinema, faz-se necessário assinalar que nossa opção por analisar este filme deve-se a um viés teórico específico, a partir do qual nos propomos a focalizar 
aspectos específicos do processo de adaptação, com o foco em questões inerentes à memória e ao jogo temporal, bem como nas complexas relações entre as práticas pedagógicas e a inclusão social.

\section{Uma história de vida: intertextos e contextos}

O diretor Luiz Villaça resolveu produzir o filme, depois de ler um livro que pertencia a seu filho de 11 anos e procurou saber mais sobre a história de vida do autor, que constava da contracapa da publicação: tratava-se de um menino, considerado irrecuperável, que se tornou um pedagogo respeitado, a partir do momento que teve uma chance. À primeira vista, uma simples adaptação para o cinema, o filme de Villaça revelou-se um desafio, tanto conceitual quanto metodológico, pela forma como o processo tradutório se desenvolve; conseguindo manter um raro equilíbrio entre a fidelidade ao texto de origem e as incursões no imaginário infantil.

Algumas das cenas, embora ausentes do livro, estão em consonância com o tom da narrativa de Ramos, que apresenta contornos mitopoéticos, ou seja, reconhecidos como ligados a esquemas míticos tradicionais. O crítico russo Eleazar Mielietinski, em A poética do mito (1987) conceitua a mitopoética como um recurso dinâmico de construção arquetipal, uma espécie de organização semântica que combina elementos da mitologia antiga com o objeto literário. O autor demonstra que muitos escritores da atualidade arquitetam suas tramas utilizando-se da fabulação mítica, de modo que as estruturas narrativas estão comprometidas com certos princípios imutáveis e eternos que intermedeiam o referencial cotidiano e as instâncias do imaginário. Diz ele:

[...] da imersão nas fontes primigênias, surge uma intensificação de certos valores peculiares, que por vezes parecem proceder de estratos aparentemente ainda mais primitivos, mas que ostentam uma capacidade significativa que os torna invulneráveis à corrosão das contribuições modernizadas. Para um escritor literário, trata-se exclusivamente de puras operações artísticas, mas nelas há implícita uma prévia proposição cultural, resultado do conflito que toda coletividade está vivendo. Essa consciência de reconstrução do mundo através da remitologização. (MIELIETINSKI, 1987, p. 440)

Consideramos que, fazendo uso das licenças poéticas (como eufemismos, metáforas e alegorias), a narrativa autobiográfica de Ramos consegue exprimir "ideias eternas", cosmogonias e escatologias, realidades inefáveis e tantos outros conteúdos que marcaram suas etapas existenciais. René Wellek e Austin Warren afirmam que "existem, realmente, atividades características como as do pensamento metafórico e mítico, um pensamento por meio de metáforas, realizado em narrativas ou em visão poética" (WELLEWK; WARREN, 1976, p. 238). 
Interessa-nos, portanto, enfatizar a maneira como a direção do filme utiliza-se de um tom emocional, acrescido de ironia, para criticar as falhas das políticas governamentais da época. Nas narrações em off feitas pelo verdadeiro Roberto Carlos Ramos, ele utiliza frases que beiram o sarcasmo para qualificar a Fundação Estadual do Bem-Estar do Menor (Febem) e sua experiência dentro dela, exatamente como no livro; mas também busca elidir alguns momentos vividos, por força das anacronias inerentes ao próprio ato de narrar.

Cumpre assinalar que uma autobiografia caracteriza-se como um ato particular de interpretação, no qual as experiências vividas são conformadas, revisadas, sintetizadas e modificadas pela mediação dos signos verbais. Segundo Gilbert Durand, a memória é eufêmica como a infância, sendo que, em sua volta ao passado,

[...] autoriza em parte a reparação dos ultrajes do tempo [...]. A memória pertence de fato ao domínio do fantástico, dado que organiza esteticamente a recordação [...]. É nisso que consiste a "aura" estética que nimba a infância; [...] é o arquétipo do ser eufêmico, ignorante da morte, porque cada um de nós foi criança antes de ser homem. (DURAND, 2002, p. 402)

Procuramos evidenciar como o enredo estabelece uma implícita comparação entre a postura educacional equivocada da antiga Febem e a ação humanitária da pedagoga francesa Margherit Duvas, que se dedicou pessoalmente à recuperação do garoto. Trata-se de um caso emblemático de conquista da cidadania - algo impensável para aqueles jovens banidos das benesses do capitalismo, que eram internados naquela espécie de reformatório, para de lá saírem mais violentos e revoltados, voltando às ruas para cometerem novos crimes.

No início, a Febem adquiriu fama, como uma espécie de colégio para crianças pobres, sob o lema: "Disciplina e Educação para Crianças Carentes". Seduzida pela propaganda do governo, em sua ingenuidade e pobreza, a mãe entregou o caçula dos nove filhos ao "colégio", tendo ele apenas 6 anos. Era uma decisão, não rara na época, quando os pais delegavam à instituição governamental não só a sobrevivência da criança, mas a responsabilidade pela realização do sonho de ter um filho formado no ensino superior e ainda capaz de cuidar da família² no futuro. Diz o livro:

Falava-se na época que a Febem era uma instituição preocupada com o bem-estar das crianças - era o local onde recebiam boa alimentação e educação escolar. A mãe e o filho estavam esperançosos. O menino pensava que estava deixando para trás uma vida miserável, e a mãe achava que um dia, quem sabe, teria um filho doutor. (RAMOS, 2004, p. 10)

Trata-se de um grande equívoco, alimentado pela publicidade a serviço do governo militar e nela acreditava a própria Margherit quando chegou ao Brasil, mas logo mudou de ideia. Eis como o episódio é ironicamente narrado na autobiografia: 
[...] queria fazer uma entrevista comigo, já que tinha a intenção de fazer uma denúncia internacional. Para ela, fazer uma denúncia de maus-tratos seria uma grande forma de me ajudar. Então pensei: "Se eu morar uma semana com essa mulher, vou roubar tudo da casa dela [...]". (Idem, ibid., p. 117)

A história é narrada de forma não linear, descrevendo a vida do menino antes e depois de sua entrada na instituição governamental. Tal estada é marcada por sucessivas fugas e passagens pelas ruas. Entretanto, cada fuga acaba reatualizando as falhas institucionais e o sentimento de impossibilidade de uma vida digna. Na convivência com outros menores excluídos, o garoto é seduzido para a marginalidade, para as drogas e os pequenos delitos.

No filme de Villaça, a reconstituição da época tem um tom naturalista, mas podem ser apontadas diversas incursões poéticas no imaginário infantil. Embora breves, algumas das sequências poéticas merecem destaque, como a da chegada com a mãe à Febem, que é representada, sob o ponto de vista infantil, como uma ida ao circo. O recurso utilizado é um fade in que permite a fusão da cena real com a imaginada pela criança, no exato momento em que os portões são abertos por um guarda/palhaço. Pátio e picadeiro se fundem e, a partir daí, são apresentados malabaristas, acrobatas e outros personagens do circo imaginário, até que um fade out estampa na tela a fria fachada da instituição.

\section{Figuras 1 e 2}

O circo imaginário (frames do filme)
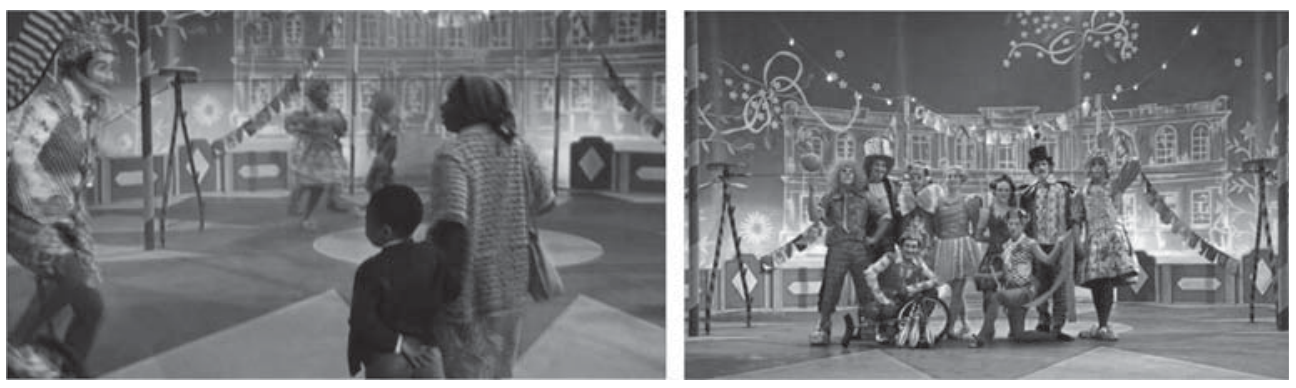

As imagens circenses conseguem representar alguns dos raros eventos que alimentariam o restrito imaginário de uma criança de 6 anos, carente e circunscrita a um espaço tão pobre. No making of do filme, os figurinistas contam como tentaram manter a verossimilhança em relação ao universo restrito e pobre de referências visuais da criança, ao fazerem as roupas de circo de papel colorido, enquanto as perucas foram feitas de balas, balões e outros materiais inusitados, para produzirem efeito com suas cores e texturas. 
Dentro da mesma proposta estética ligada ao repertório infantil, é construída a cena da professora de Educação Física que aparece como um hipopótamo. Tais representações fantasiosas aparecem também no livro de Ramos, como frutos de sua fértil imaginação, que lhe permitia fugir das agruras da vida. São estratégias de resistência singulares, vividas e contextualizadas a partir de uma infância estigmatizada, das quais outro exemplo pitoresco é a sequência de uma tentativa de assalto ao banco, que a criança imagina ter sido realizada pela família e narra fantasiosamente à pedagoga. Tudo é representado como uma espécie de paródia de programas de televisão dos anos de 1970 e de artistas como os Jackson Five.

Destarte, poderíamos dizer que o próprio narrador/protagonista seria um intérprete de seu passado, pois ele irá alterá-lo ou modificá-lo, dependendo das associações criadas em determinadas circunstâncias e em momentos diferenciados. Para Durand (op. cit., p. 403), "A memória - como imagem - é essa magia vicariante pela qual um fragmento existencial pode resumir e simbolizar a totalidade do tempo reencontrado".

Além disso, sabe-se que, no cinema, a questão da representação precisa ser relativizada em virtude das metamorfoses do imaginário decorrentes da diegese fílmica. Arlindo Machado considera que o conceito de verossimilhança não deve ser demasiadamente "escrupuloso para as liberdades do mundo diegético" (MACHADO, 2007, p. 9). É o que percebemos nas reconstruções poéticas que tentam mostrar na tela como a criança imagina a realidade e como ela fantasia sobre o que viu, vê ou verá. Daí a ênfase na imaginação e na fantasia em algumas cenas do filme, mostrando como a criança rompe os limites entre o vivido e o imaginado, para driblar as próprias carências e necessidade de atenção.

Uma sequência marcante que explora o imaginário em aberto, sob a perspectiva da cosmovisão infantil, é a do alegórico encontro de Roberto com um dos líderes dos meninos de rua. A cena imaginada pela criança mostra o jovem delinquente Cabelinho de Fogo descendo uma escadaria, vestido como nos musicais da tevê, cercado de outros meninos que lhe prestam reverência enquanto vão praticando vários furtos.

\section{Figuras 3 e 4}

Da fantasia à crua realidade (frames do filme)
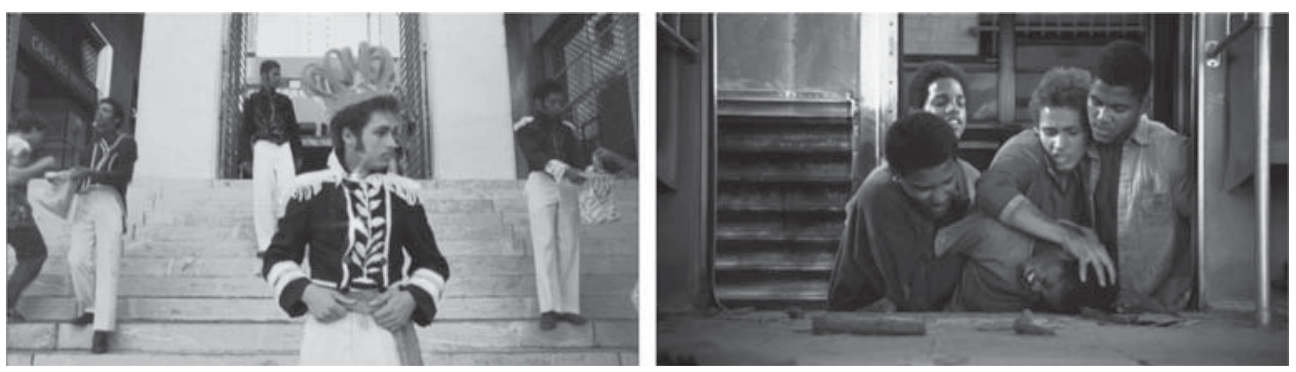
O contraste é violento com a brutalidade destes mesmos delinquentes que, a seguir, arrastam o garoto para os trilhos do trem, onde o violentam entre vagões estacionados. A cena de abertura do filme mostra Roberto aos 13 anos, ferido e sobre os trilhos, após este trágico episódio de "rito iniciático".

\section{Figura 5}

Frame da abertura do filme

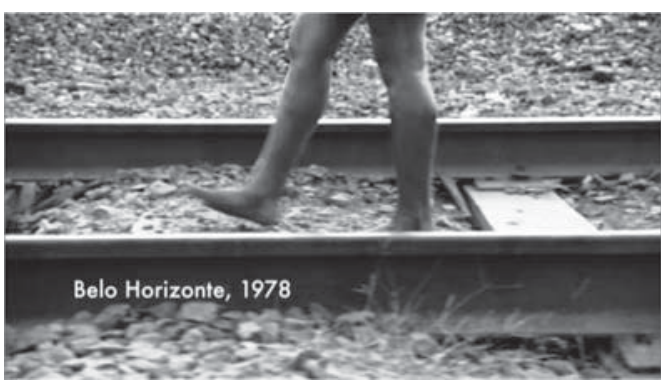

\section{Figura 6}

Frame do banho purificador

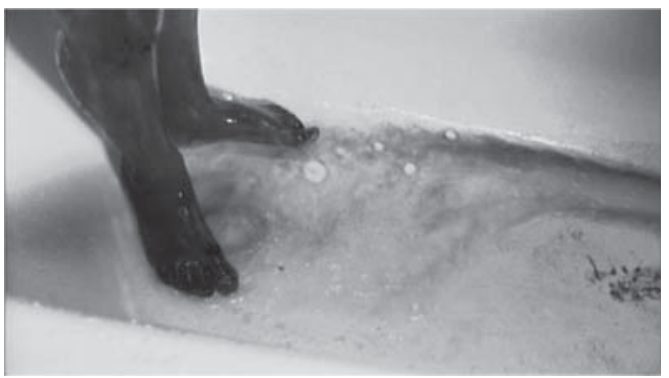

É o momento da mudança radical na vida do menino, que resolve refugiar-se na casa de Margherit, trancando-se no banheiro, de onde só sai depois de muita insistência, no dia seguinte. Nesse momento, um longo banho purificador adquire contornos míticos, pois simboliza o momento de decisão em romper com a vida de fugas e capturas, quando o adolescente aceita a ajuda da pedagoga estrangeira. Interpretamos o banho como um dos motivos míticos relevantes que se expressam na representação simbólica de fatos que se pretende redimensionar. Cenas e imagens ligadas aos elementos líquidos permitem estabelecer uma relação com as teorias sobre o pensamento mítico e o tempo cíclico, que foram desenvolvidas em diversas obras de Mircea Eliade, Ernst Cassirer ou Gaston Bachelard e que expressam, em síntese, que as águas conservam invariavelmente sua função: elas desintegram, eliminam 
as formas, "lavam os pecados", são ao mesmo tempo purificadoras e regeneradoras. É nesse sentido que consideramos a narrativa permeada pelo simbolismo das imagens aquáticas, como apontaremos mais adiante, em outras sequências do filme analisado.

Interessa-nos destacar esta e outras cenas similares, como uma forma de retomar o tempo e o espaço para reescrever um projeto existencial, já que a atividade mnemônica não pode ser considerada um análogo do vivido. Essa compreensão levanos a perceber, no filme, como as licenças poéticas e os eufemismos da autobiografia são adequadamente transpostos para o meio audiovisual e, algumas vezes, expandidos, dando origem a sequências inexistentes no livro, porém pertinentes ao imaginário infantil. O processo de adaptação leva-nos ao pensamento de Ismail Xavier:

\begin{abstract}
Deve-se pensar o cinema a partir das ilusões da técnica [...] seu encantamento persiste porque o dado crucial em jogo não é tanto a imitação do real na tela - mas a simulação de um certo tipo de sujeito-do-olhar pelas operações do aparato cinematográfico. (XAVIER, 1988, p. 377)
\end{abstract}

Na época mostrada no filme, por volta de 1970, a instituição governamental de amparo ao menor havia passado por uma grande reformulação e, além de abrigar os jovens que haviam cometido delitos, servia também como uma espécie de orfanato. A Febem não estava aparelhada nem física, nem pedagogicamente para a tarefa, o que impedia qualquer tentativa de ação educativa, pois esta envolvia relações intergeracionais que Roberto só veio a conhecer graças à intervenção de Margherit Duvas. Antes disso, na ausência de qualquer projeto pedagógico que o motivasse, o menino optava pelas inumeráveis fugas, negando-se até mesmo a ser alfabetizado.

\footnotetext{
Assim começou o meu contato com as pessoas incompetentes [...]. Dessa maneira critico aquele tipo de profissional que conheci no contexto de minha ida para a escola. Aquela escola em particular; com seus péssimos educadores, assistentes sociais, medíocres médicos e psicólogos incompetentes. (RAMOS, 2004, p. 27)
}

Há poucas cenas que revelam as várias formas que a truculência pode assumir, dentro de uma unidade educacional corretiva, mas elas são tratadas com uma ironia mordaz. A câmera focaliza pernas de meninos a correr, enquanto a voz em off explica que as pessoas não entendiam por que ele fugia. Ironicamente, o narrador diz que, dentro daquela escola, quando ele tinha sede davam água (e aparece a imagem de um pequeno ator sendo afogado); ou ainda que, às vezes, ele tinha a "oportunidade" de dormir em um quarto reservado (e, na tela, o menino é jogado dentro de uma cela solitária). Contudo, apesar de algumas cenas violentas, nada no filme é folhetinesco; a ditadura militar é apenas sugerida, como um pano de fundo esmaecido pelo ponto de vista do narrador/criança. Acreditamos que, por ser uma narrativa centrada 
na sensibilidade e nos afetos, posturas negativas e autoritárias não mereceriam ser diretamente questionadas ou cruamente expostas, uma vez que já sobejamente conhecidas.

Em que pese a crueldade da sequência inicial, embora seja uma história densa, o filme não é piegas, o que é confirmado pela direção contida e pela fotografia despojada e naturalista. Diríamos que, enquanto a pobreza é estetizada nas coloridas cenas iniciais, a violência também é estetizada, tanto nas cenas externas, dos assaltos e das drogas, quanto no espaço interno da instituição. Um exemplo é o tom paródico que a direção imprime a uma espécie de "coreografia" do assalto praticado pelos pivetes nas ruas; alegoricamente mostrado como um jogo de futebol, ao som de "Salve a Seleção". Tal opção revela uma alusão ao fato de o governo militar explorar o sucesso do futebol brasileiro como forma de propaganda ideológica. Porém, esta sequência demonstra também a força do impulso lúdico e da ironia na concepção do filme.

Um dos recursos cinematográficos dignos de nota é a exploração cromática das imagens, como estratégia usada para delinear os limites entre a vida da criança na favela, a privação da liberdade entre os muros da instituição. Atualizam-se, assim, alguns paradigmas declarados ou subjacentes que referenciam a utilização da cor no cinema. No primeiro momento são usadas cores alegres e quentes, em poético contraponto com os lençóis brancos que a mãe lavadeira estendia nos varais da casa na favela. Percebe-se certa idealização da figura materna, própria das crianças de tenra idade. A partir da entrada na Febem, as cores passam a ser mais frias, delineando um espaço impessoal, azulado e cinzento. As cores quentes só voltam, significativamente, depois do encontro com Margherit.

\section{Figuras 7 e 8}

Nuanças cromáticas da escola/reformatório (frames do filme)
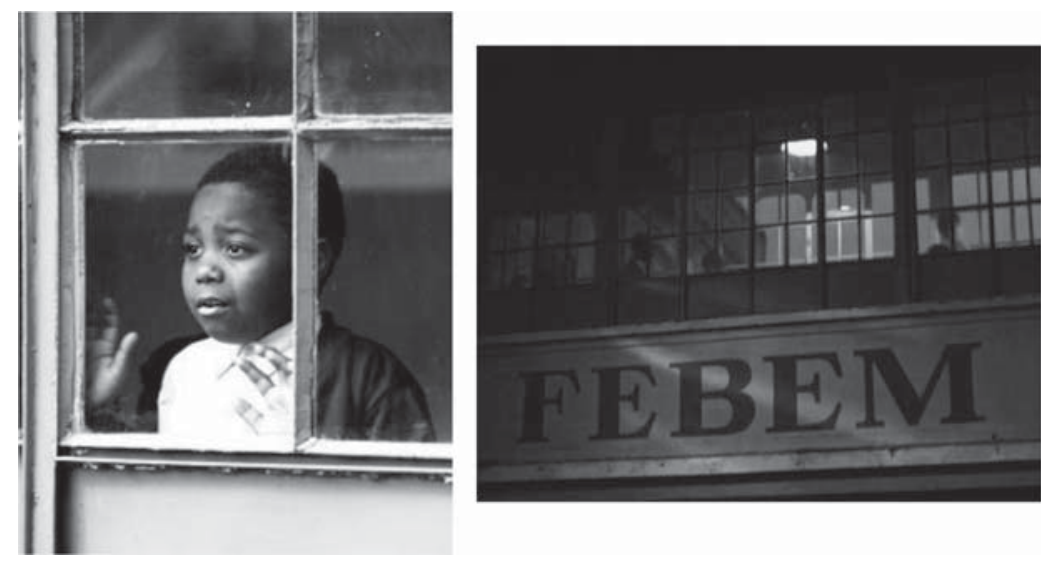
A instituição é apresentada com imagens mais próximas da neutralidade, não se aprofundando críticas sobre seus discutíveis "métodos" disciplinares, por exemplo. É nesse sentido que o filme é fiel ao livro, pois o diretor também opta pelos eufemismos e metáforas, ao denunciar as atrocidades cometidas dentro daqueles muros, sem a explicitação de detalhes.

Teoricamente falando, mesmo com intenção autobiográfica, é óbvio que um texto é somente um texto - no sentido mais amplo da palavra -, é uma representação, um interpretante possível, entre muitos outros, ou seja, é uma leitura circunstancial de eventos passados. A concepção tradicional do gênero autobiográfico, postulada por Philippe Lejeune em 1975, apontava como condição uma tripla identidade nominal,

L'identité se définit à partir des trois termes: auteur, narrateur et personnage. Narrateur et personnage sont les figures auxquelles renvoient, à l'intérieur du texte, le sujet de l'énonciation et le sujet de l'énoncé; l'auteur, représenté à la lisière du texte par son nom, est alors le référent auquel renvoie, de par le pacte autobiographique, le sujet de l'énonciation. (LEJEUNE, 1975, p. 35)

Tendo forjado a expressão "pacto autobiográfico", o autor francês mantém um site dedicado ao tema, que tem como objeto todas as formas autobiográficas, tais como discursos, crônicas, cartas, diários e similares, onde explica:

Le pacte autobiographique s'oppose au pacte de fiction. Quelqu'un qui vous propose un roman (même s'il est inspiré de sa vie) ne vous demande pas de croire pour de bon à ce qu'il raconte [...]. L'autobiographe, lui, vous promet que ce que qu'il va vous dire est vrai, ou, du moins, est ce qu'il croit vrai. Il se comporte comme un historien ou un journaliste, avec la différence que le sujet sur lequel il promet de donner une information vraie,c'est lui-même [...]. On ne lit pas de la même manière une autobiographie et un roman. (LEJEUNE, s.d.) ${ }^{4}$

\section{Do livro ao filme: a prática da "Pedagogia do Amor"}

A narrativa contém elipses e algumas cenas alegóricas próprias da linguagem do cinema. Todavia, nos permite sutilmente perceber que, ao sair dos muros da escola/reformatório e ir para a casa da pedagoga, o garoto começa a ter contato diário e progressivo com a verdadeira "Pedagogia do Amor" e suas 15 lições, como o autor as nomeia: Noção de Tempo e Espaço, de Autoestima, de Relacionamento, de Reciprocidade, de Espiritualidade, de Solidariedade, de Humildade, de Felicidade, de Coabitação, de Tolerância, de Sensibilidade, de Família, de Continuidade, de Extraordinariedade e de Magnanimidade. ${ }^{5}$ 


\section{Figura 9}

Após a última fuga (frame do filme)

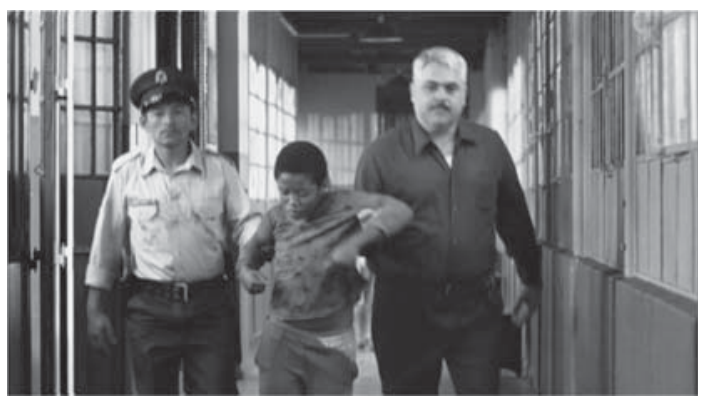

Figura 10

O primeiro encontro (frame do filme)

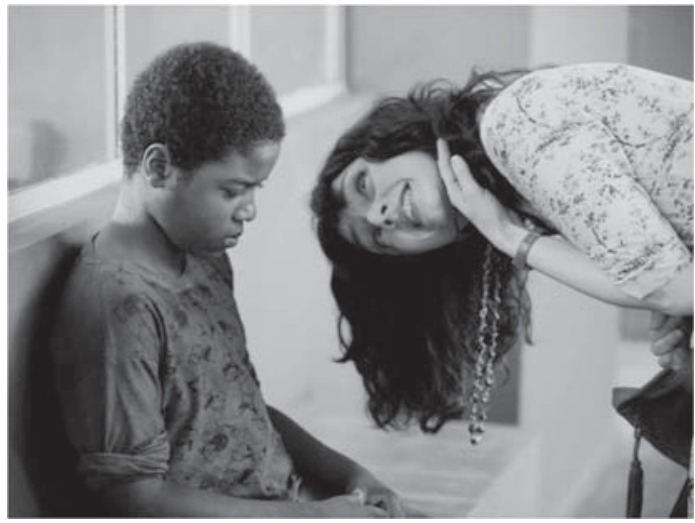

No primeiro encontro, vemos um menino negro, sujo, sério, novamente capturado, sentado em um banco no corredor da Febem. Revoltado e desconfiado, ele não quer dar atenção à pedagoga, mas ela insiste e se abaixa. No livro, a cena é assim narrada:

Pela primeira vez na vida, naquele lugar, alguém se aproximou de mim e, antes de falar alguma coisa referente à minha cor da pele, ao meu cheiro de xixi, ao meu nariz escorrendo catarro ou ao meu cabelo com piolhos, me olhou bem nos olhos e fez uma das coisas mais fantásticas que um ser humano pode fazer para o outro, que é sorrir com os olhos. Assim ela fez e me disse algumas poucas palavras que, para mim, tiveram um significado sagrado: - "Com licença, por favor. Eu gostaria de falar com você". [...] Quando a francesa me disse "Por favor", eu achei que ela fosse louca, pois, até então, ninguém havia ma tratado daquela maneira. (RAMOS, 2004, p. 107)

Com certa resistência, o garoto começa a falar e ela a gravar em seu velho gravador. Depois de várias tentativas frustradas, Margherit o recebe na própria casa, 
alimenta-o, dá-lhe noções de higiene, de educação e, sobretudo, muita compreensão e carinho. Aos poucos, ele vai narrando todas as suas experiências dentro dos muros da "escola" e também nas inúmeras fugas, usando metáforas e muita imaginação. Desde o primeiro encontro, a pedagoga perguntou como poderia mudar a realidade daquele menino. E, realmente, ela o fez, de maneira exemplar.

Procurando ser fiel à tônica do livro, a narrativa fílmica busca a espontaneidade e a pureza na reconstituição das três idades do protagonista. A proposta do diretor do filme é construída sobre a difícil, complicada e afetuosa relação entre a pedagoga francesa e o menino brasileiro que ela adotou como filho e levou para a França, quando não lhe permitiram mais permanecer no Brasil. $\mathrm{O}$ (re)agenciamento das imagens é regido pelo ritmo dos sentimentos, indo do prosaico e lírico cotidiano ao fantástico e surpreendente limite do surreal. Segundo Gilbert Durand, o problema da existência de uma "memória afetiva"

[...] significa exatamente essa possibilidade de síntese entre uma representação revivescente, lavada da sua afetividade existencial de origem e a afetividade presente. A recordação mais funesta é desarmadilhada da sua virulência existencial e pode entrar asim num conjunto original, fruto de uma criação. (DURAND, 2002, p. 402)

Através de episódios repletos de significados implícitos sobre a prática das lições da pedagogia amorosa, o filme apresenta, além da cena do banho, mais três momentos ligados à simbologia da água, nos quais ambos passam pelo rito de iniciação e "renascem" para uma vida em comum. Uma das mais tensas do filme, a cena da inundação da casa, tem contornos míticos. Após um ano de convivência e aprendizado constante, o garoto sente-se desesperadamente abandonado ao saber que o visto de permanência da educadora francesa estava vencido. No livro, tem-se: "Então inundei a casa dela, certo de que ao chegar ela me colocaria para fora e eu teria a certeza de que ninguém realmente gostava de mim..." (RAMOS, 2004, p. 143).

Quando Margherit chega e pergunta se ele havia esquecido a torneira aberta, ele responde que foi de propósito. Em lugar da esperada reação violenta, ela o abraça com força, afaga seus cabelos e diz chorando que o ama. Após narrar o episódio, o autor comenta:

Segundo os ensinamentos de Margherit, a Pedagogia do Amor deve ser aplicada a todas as pessoas, sobretudo àquelas que são consideradas as que mais tumultuam, as mais complicadas. [...] a proposta dessa forma de ensinamento é ter sempre um pouco mais de perseverança. Ter sempre um pouco mais de insistência para resolvermos aquilo que denominamos "situações problemas". (Idem, ibid., p. 149)

Então, ele reproduz a frase da educadora e mãe adotiva, descrevendo sua atitude amorosa e inesperada: 
[...] "Quando Piaget falhar, quando Vigotsky não der certo, abrace seu aluno como ser humano, e tudo vai dar certo". [...] Foi nesse instante que ela me abraçou e realmente me conquistou. E aquele velho motivo do nosso primeiro encontro - fazer uma denúncia internacional de maus-tratos às crianças do Brasil - tinha dado lugar a uma outra coisa: salvar uma criança do Brasil, em particular. Uma criança pela qual ela havia maternamente se apaixonado, um tal de Robertô. (Ibid., p. 150)

Segundo Manuel Jacinto Sarmento, do Instituto de Estudos da Criança da Universidade do Minho (Portugal), quando se trata de educação, tudo depende do trabalho pedagógico realizado a partir do aprofundamento do conhecimento sobre as crianças e das suas relações com os outros.

Se tal perspectiva está correcta, a escola transformar-se-á. É nesta "originalidade" que poderão surgir potenciais emancipatórios para as crianças, que para se realizarem precisam que os adultos aceitem negociar princípios e discursos sobre e com elas, infundindo desta forma outros significados à acção educativa e às relações intergeracionais. (SARMENTO apud DELGADO; MULLER, 2006, p. 16)

Os outros dois momentos simbólicos que destacamos no filme não aparecem no livro, mas servem para revelar uma consciência marcada pela tensão entre o imaginário e os espaços urbanos efetivos. No primeiro deles, o filme mostra o esforço de ambos, até que Roberto consegue ler sozinho Vinte mil léguas submarinas, mergulha naquele universo mitopoético e descobre o poder e a magia das palavras. No filme, as imagens do fundo do mar, provenientes da narrativa de Júlio Verne, são iconizadas através do desenho animado, com o recurso à hibridação das imagens. É desta perspectiva que se vê a tela configurar-se como o espaço de saturação metafórica, ou até mesmo de uma abstração alegorizante, em que o garoto se imagina visitando o fundo do mar.

O episódio serve de gancho para um dos momentos mais marcantes do filme, quando o menino é levado para conhecer o oceano Atlântico. Inicia-se com o mistério criado pela mãe adotiva durante a viagem de ônibus, até quando ela o conduz com os olhos vendados para a praia e ele sai correndo, fascinado, em direção às ondas.

\section{Figura 11}

A surpresa (frame do filme)

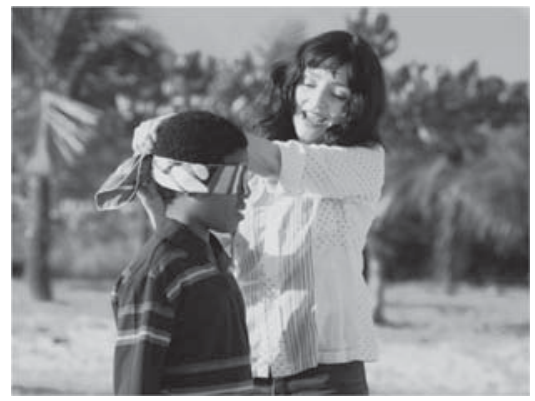




\title{
Figura 12
}

O mar (frame do filme)

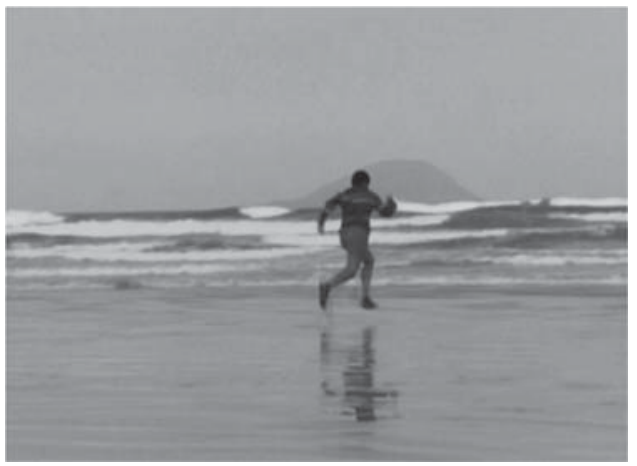

Curiosamente, este episódio não é relatado no texto de origem, mas consideramos ser ele um momento síntese, uma espécie de metonímia das descobertas feitas pelo menino, graças à sensibilidade daquela que ele chama de "fada madrinha". Devido a essa licença poética, o diretor consegue fazer uma síntese visual alusiva às oportunidades que Margherit ofereceu ao jovem de ampliar seus horizontes. Em entrevista, o diretor afirma que viu na vida de Roberto um caminho para mostrar o quanto poderíamos ganhar se colocássemos a educação e a cultura um pouco que fosse à frente das discussões econômicas.

\begin{abstract}
Aprendi nos filmes de Truffaut, de Ettore Scola e do neorrealismo a falar do real buscando transformações [...]. Sei que este filme segue por uma trilha contracorrente ao que se faz nos cinemas por não ter medo da emoção, da doçura. Mas eu não quero pôr o dedo em uma ferida sem ter uma transformação possível para sugerir a essa realidade. E há uma cena de corrida na praia que é um beijo meu em "Os incompreendidos", de Truffaut. (VILLAÇA, 2009)
\end{abstract}

O conflito de culturas e de faixas etárias é trabalhado de uma forma poética nos dois filmes. No entanto, ao contrário do clássico Os incompreendidos (de François Truffaut, 1958), que retrata a indiferença e frieza dos pais e educadores em relação ao menino, o diretor brasileiro consegue expressar as boas intenções da mãe verdadeira, além do idealismo e carinho da mãe adotiva.

\section{O poder da palavra na construção da cidadania}

Cidadania é conquista e se realiza a partir da conscientização dos integrantes de uma sociedade fundada na justiça social - o que parecia inviável no caso da vida do menor brasileiro, que viveu dos 6 aos 13 anos como um interno da Febem, na cidade de Belo Horizonte (de 1971 a 1978). Beto Pivete era considerado "um caso 
perdido", pois fora usuário de drogas, tendo efetuado furtos nas ruas e tinha 132 fugas contabilizadas em sua ficha.

$\mathrm{Na}$ época, sofriam-se os impactos do contexto brasileiro, em plena ditadura militar. Decorrente do entendimento "militarizado" da questão, durante o governo Médici (em 1964), foi criada a Fundação Nacional do Bem-Estar do Menor (Funabem), à qual foi delegada a implantação da Política Nacional do Bem-Estar do Menor. Na década seguinte, ainda sob a égide dessas políticas, surgiu a Fundação Estadual do Bem-Estar do Menor (Febem) - que teve sedes instaladas em vários estados do país e cuja proposta era a responsabilidade pela educação de crianças carentes e adolescentes infratores. O Código de Menores era a legislação que regulava o atendimento nas unidades de internação, naquela época. Hoje, o termo "menor" é considerado politicamente incorreto e a memória que se tem da antiga Febem são diversas rebeliões e equívocos na recuperação de jovens infratores, com raríssimos resultados positivos.

O contador de histórias recebeu um selo da Unesco, como reconhecimento a um projeto que mostra como educação e a cultura são efetivos pilares da inclusão social. Consideramos de interesse pedagógico, pela qualidade e abrangência da iniciativa, o site oficial do filme que inclui O Projeto Escola, com destaque para o tema: "Cinema, educação e juventude" ${ }^{6}$

\section{Figura 13}

Imagem do site oficial do filme

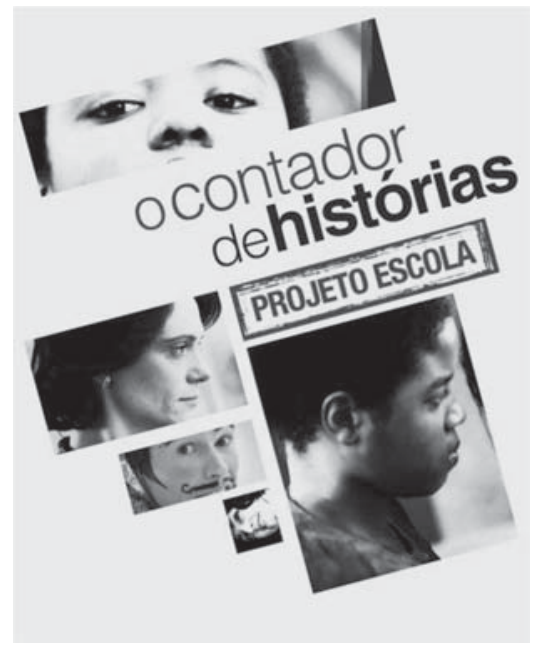

Em síntese, a narrativa fílmica nos lembra que, embora saibamos que a educação atualiza a inclinação potencial dos homens à vida comunitária ou social, 
ninguém nasce cidadão. Segundo Sarmento (apud DELGADO; MULLER, 2006, p. 17): “[...] uma educação para a cidadania só o é enquanto compromisso com a criação da cidade dos homens, de mudança social indutora de um desenvolvimento sustentado, equitativo e justo". O autor português afirma que não há cidadania sem cidade; isso porque as condições do exercício dos comportamentos cívicos supõem, por definição, a existência da civitas, ou seja, do espaço social e comunitário que permita a realização das interações, numa base de igualdade e de respeito pelos direitos de cada um.

Voltando no tempo, lembramos que, por volta dos séculos VIII e VII a.C., os helenistas assinalam o nascimento da polis, como um acontecimento decisivo que provocou grandes alterações na vida humana e nas relações sociais, inexistentes nas comunidades tribais primitivas. A cidade grega estava centralizada na ágora (praça pública), espaço onde se debatiam os problemas de interesse comum, com ênfase na justa distribuição dos direitos dos cidadãos. Como o homem e a polis formavam um todo único, o conceito de Paideia girava em torno de dois termos seminais: ethos e arete. Cumpre lembrar que o radical grego da palavra ética não dizia propriamente respeito à formação moral nem aos valores do indivíduo ou institucionais, como hoje são entendidos. Ethos significava um lugar específico no enigma da physis (o próprio real), um lugar de eclosão ou de desvelamento, formado pela verdade de cada um. Entendida como a mais completa realização possível do cidadão como parte integrante da polis, a palavra arete implicava a excelência tanto física (para a guerra e os jogos) quanto intelectual (para ser comprovada através do domínio da palavra nas assembleias, no fórum e nas artes). Cabia à Paideia oferecer as condições de tal excelência.

Segundo Aranha e Martins (1993), a Paideia foi repensada em seus fundamentos por Platão e depois por Aristóteles, vindo a fundar o cânone ocidental da formação do homem, no sentido do ideal da educação na Grécia antiga. Na cultura latina, seu sentido fundiu-se ao Humanismo. Contudo, nesses desdobramentos perdeu-se o sentido da cidadania: ethos virou moral e arete, virtude. Na contemporaneidade, as ciências humanas têm procurado retomar as dimensões implicadas nos conceitos de ethos e de arete, com vistas à recuperação do aspecto político na formação plena do cidadão de hoje.

Inegável é que tanto a escrita quanto a fala têm função mediadora fundamental em todas as instâncias da vida humana, sendo também inegável o poder da palavra (logos). No dizer de Paul Zumthor (1975, p. 93), "a identidade da cultura grega se funda e configura em torno das suas criações poéticas". O fato de o pedagogo Roberto ter feito da arte de contar histórias uma de suas atividades favoritas faz com que a força da palavra constitua o cerne da narrativa autobiográfica que dá origem ao filme aqui analisado. 
O final do filme apresenta o próprio biografado em ação, aos 43 anos, no centro de uma praça pública da capital mineira. Na ágora contemporânea, Roberto conta histórias para crianças e seus pais, todos completamente envolvidos na magia de suas palavras.

\section{Figura 14}

O contador de histórias em ação (frame do filme)

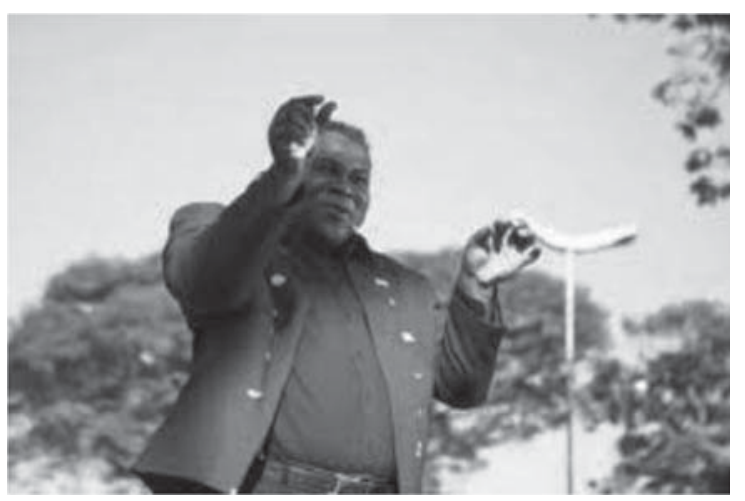

Segundo Walter Benjamin, contar uma história é uma tentativa de burlar a finitude, já que este ato mantém a tradição viva. Uma história sempre pode se encaixar em outra, e em outra, e continuar infinitamente. O narrador nato é aquele que narra sua própria vida, bebendo também da experiência dos outros.

[...] o narrador entra na categoria dos professores e dos sábios. Ele dá conselho - não como provérbio: para alguns casos - mas como o sábio: para muitos. Pois lhe é dado recorrer a toda uma vida. (Uma vida, aliás, que abarca não só a própria experiência, mas também a dos outros. Àquilo que é mais próprio do narrador acrescenta-se também o que ele aprendeu ouvindo.) Seu talento consiste em saber narrar sua vida; sua dignidade em narrá-la inteira. (BENJAMIN, 1983, p. 74)

A câmera caminha pelos rostos atentos, num jogo que procura captar a performance do contador de histórias e seus efeitos na plateia. Nesta espécie de apêndice no filme, Roberto, tal qual o narrador benjaminiano, deixa "a mecha de sua vida consumir-se integralmente no fogo brando de sua narrativa" (idem, ibid.). Trata-se de um momento celebrativo, pois traz uma cena da vida "real", numa espécie de passe de mágica que reitera a força da tradição da narrativa oral, em sua capacidade de encantar e de transformar o mundo. As mesmas qualidades poderiam ser atribuídas ao filme, pois, apesar da força das anacronias inerentes às narrativas em primeira pessoa, a transposição para o cinema consegue superar, como ato estético inventivo, 
os fatos vivenciados ou até mesmo transubstanciá-los, estatuindo-se como uma narrativa cinematográfica de contornos mitopoéticos.

\section{Ficha técnica}

Filme: O contador de histórias, Brasil (2009).

Direção: Luiz Villaça.

Roteiro: Mauricio Arruda, José Roberto Torero, Mariana Veríssimo, Luiz Villaça.

Fotografia: Lauro Escorel.

Elenco principal: Maria de Medeiros, Marco Ribeiro, Paulo Henrique Mendes.

Elenco coadjuvante: Cleiton Santos, Malu Galli, Ju Colombo, Daniel Henrique da Silva, Ricardo Perpétuo, Matheus de Freitas, Victor Augusto da Silva, Teuda Bara, Jacqueline Obrigon, Luciana Carnieli, Chico Díaz, Paulo Federal, Maurício Marques, Laerte Mello, Rhena de Faria, Cesar Lopes, Montanha Carvalho.

\section{Notas}

1. Membro da Associação Internacional dos Contadores de Histórias e Valorizadores da Expressão Oral Mundial, com sede em Marselha, na França, o brasileiro Roberto foi eleito, nos EUA, em 2001, um dos maiores contadores de histórias. Tendo concluído o ensino médio na França, é pedagogo pela Universidade Federal de Minas Gerais (UFMG), pós-graduado em Literatura Infantil pela Pontifícia Universidade Católica de Minas Gerais (PUC-MG) e mestre em Educação pela Universidade Estadual de Campinas (Unicamp).

2. O que dificilmente ocorria, embora Roberto retorne adulto e formado para rever a mãe na minúscula casa da favela e para auxiliar a família.

3. Tradução livre da autora: "A identidade define-se a partir de três termos: autor, narrador e personagem. Narrador e personagem são as figuras que remetem, no interior do texto, ao sujeito de enunciação e ao sujeito do enunciado; o autor representado textualmente por seu nome é ainda o referente que remete, em termos do pacto autobiográfico, ao sujeito de enunciação".

4. Tradução livre da autora: “O pacto autobiográfico opõe-se ao pacto da ficção. Qualquer pessoa que lhe proponha um romance (mesmo que seja inspirado em sua vida) não exige que você acredite em tudo que é narrado [...]. O 'autobiógrafo' lhe promete que o que será dito é verdadeiro, ou, pelo menos, é aquilo que ele crê verdadeiro. Ele comporta-se como um historiador ou um jornalista, com a diferença que a pessoa sobre a qual ele lhe promete dar uma informação verdadeira é ele mesmo [...]. Não se lê da mesma maneira uma autobiografia e um romance".

5. Já adulto, o pedagogo demonstra ter incorporado as lições da mestra, ao passar a adotar 13 menores e também por acolher em sua casa mais 12 jovens estudantes carentes. Este gesto demonstra como ele procura dar continuidade ao trabalho da educadora francesa, que faleceu em 1985, quando ele tinha 20 anos.

6. O Projeto Escola promove sessões educativas gratuitas seguidas de debate, oferece site para ampliação de pesquisa e guias impressos e digitais dirigidos a professores e alunos do ensino médio no Brasil. Alguns dos objetivos do projeto são aproximar currículo e cotidiano, dando novos significados aos conteúdos propostos, ampliar o repertório cultural dos alunos e permitir que a magia do cinema ganhe novos contornos educativos em sala de aula, dinamizando aprendizados e reflexões. 


\section{Referências}

ARANHA, M.L.A.; MARTINS, M.H.P. Filosofando: introdução à filosofia. São Paulo: Moderna, 1993.

AUMONT, J. A estética do filme. São Paulo: Papirus, 2002.

BACHELARD, G. A água e os sonhos. São Paulo: Martins Fontes, 2009.

BENJAMIN, W. Textos escolhidos. São Paulo: Câmara Brasileira do Livro, 1983.

BUFFA, E.; NOSELLA, P.; ARROYO, M. Educação e cidadania: quem educa o cidadão? São Paulo: Cortez, 1996.

CAMPBELL, J. Mitologia na vida moderna. Rio de Janeiro: Rosa dos Tempos, 2002.

CASSIRRER, E Linguagem e mito. São Paulo: Perspectiva, 2006.

DURAND, G. As estruturas antropológicas do imaginário. São Paulo: Martins Fontes, 2002.

ELIADE, M. Imagens e símbolos. São Paulo: Martins Fontes, 1990.

HOLDEN, C.; CLOUGH, N. Children as citizens: education for participation. London: Jessica Kingsley, 1998.

LEJEUNE, P. Le pacte autobiographique. Paris: Seuil, 1975.

MACHADO, A. O sujeito na tela: modos de enunciação no cinema e no ciberespaço. São Paulo: Paulus, 2007.

MIELIETINSKI, E.M. A poética do mito. Rio de Janeiro: Forense Universitária, 1987.

PILLETI, N. História da educação. São Paulo: Ática, 1990.

RAMOS, R.C. A arte de construir cidadãos: as 15 lições da Pedagogia do Amor. São Paulo: Celebris, 2004.

SARMENTO, M.J. (Org.). Autonomia da escola: políticas e práticas. Porto: Asa, 2000.

SARMENTO, M.J. Infância, exclusão social e educação como utopia realizável. Educação E Sociedade, Campinas, v. 23, n. 78, p. 257-264, abr. 2002.

SARMENTO, M.J.; CERISARA, A.B. Crianças e miúdos: perspectivas sociopedagógicas da infância e educação. Porto: Asa, 2004.

SARMENTO, M.J. A construção social da cidadania na infância. Conferência IV. Congresso da Texto Editora. Lisboa: Texto Editora, 2006. 
SAVIANI, D. História das idéias pedagógicas no Brasil. Campinas: Autores Associados, 2007.

SCHILLER, F. A educação estética do homem. São Paulo: Iluminuras, 1995.

VERNANT, J.-P. As origens do pensamento grego. São Paulo: Difel, 1977.

WELLEK, R.; WARREN, A. Teoria da literatura. Lisboa: Europa-América, 1976.

XAVIER, I. Cinema: revelação e engano. In: NOVAES, A. et al. O olhar. São Paulo: Cia das Letras, 1988. p. 367-384.

ZUMTHOR, P. Langue, texte, énigme. Paris: Minuit, 1975.

\section{Referências na internet}

BITO, A. Entrevista: Luiz Villaça. Cineclick, 6 ago. 2009. Disponível em: <http://www. cineclick.com.br/entrevista/carregar/titulo/luiz-villaca/id/186>. Acesso em: 13 jan. 2010.

DELGADO, A.C.C.; MÜLLER, F. Infâncias, tempos e espaços: um diálogo com Manuel Jacinto Sarmento. Currículo sem Fronteiras, v. 6, n. 1, p. 15-24, jan./jun. 2006. Disponível em: <http://www.curriculosemfronteiras.org/vol6iss1articles/sarmento. pdf $>$. Acesso em: 3 jan. 2010.

LEJEUNE, P. Qu'est-ce que le pacte autobiographique? In: Autopact: site proposé par Philippe Lejeune. Disponível em: <http://www.autopacte.org/pacte_autobiographique. html>. Acesso em: 30 set. 2009

PROJETO ESCOLA. O contador de histórias. Disponível em : <http://wwws.br.warnerbros. com/ocontadordehistorias/projetoescola>. Acesso em: 10 jan. 2010.

ROBERTO CARLOS RAMOS. Disponível em: <http://www.robertocarloscontahistoria. com>. Acesso em: 12 dez. 2009.

VILLAÇA, L. Entrevista. O Globo, 4 ago. 2009. Disponível em: <http://oglobo.globo. com/cultura/mat/2009/08/04/luiz-villaca>. Acesso em: 18 dez. 2009.

Recebido em 28 de junho de 2011.

Aprovado em 11 de maio de 2012. 